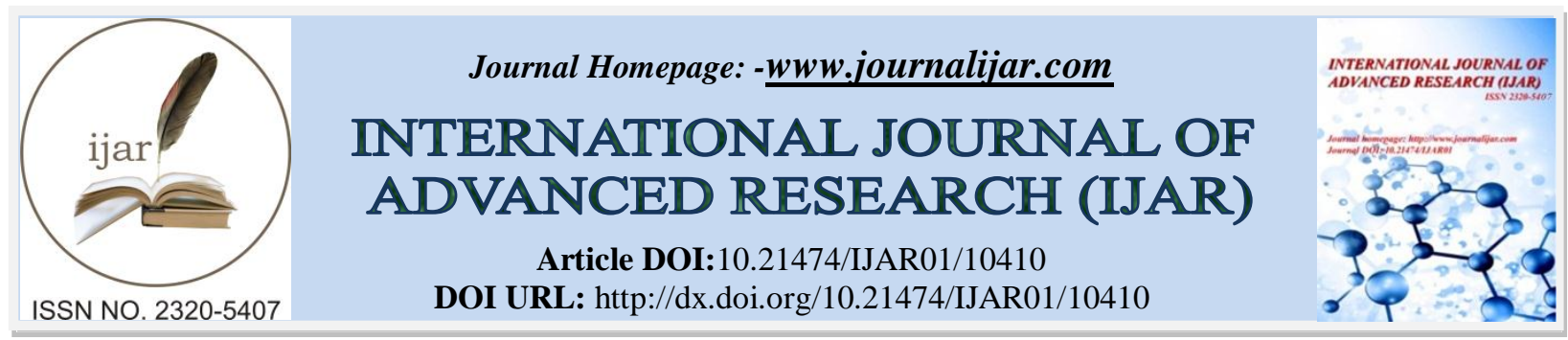

RESEARCH ARTICLE

\title{
A STUDY ON AWARENESS OF ICT AMONG PROSPECTIVE TEACHERS IN TRICHY DISTRICT
}

\section{Suguna ${ }^{1}$ and Dr. E. Neelamegam ${ }^{2}$}

1. Assistant Professor, Department of Education, Annai College of Education, Kumbakonam.

2. Assistant Professor in Education, Annai College of Education, Kumbakonam.

\section{Manuscript Info}

Manuscript History

Received: 30 November 2019

Final Accepted: 31 December 2019

Published: January 2020

Key words:-

Awareness, ICT and Prospective

Teachers

\begin{abstract}
The study was conducted to find out the level of awareness in ICT among prospective teachers with respect to gender, locality, medium of instruction and type of management. Survey method of research has been used in the present study. The Researcher was adapted Awareness towards ICT Scale developed and standardized by suguna (2017). The researcher randomly selected 294 prospective teachers in and around Trichy district of Tamilnadu. The study results reveal that the most of the prospective teachers have moderate level of awareness towards ICT. It was found that, (i) there is significant difference between male and female of prospective teachers in their ICT Awareness. (ii) There is significant difference between Tamil and English medium of prospective teachers in their ICT Awareness. (iii) There is significant difference between rural and urban area prospective teachers in their ICT Awareness.
\end{abstract}

Copy Right, IJAR, 2020,. All rights reserved.

\section{Introduction:-}

Information and Communication Technology is the fusion of computers and telecommunications. It describes exciting and innovative ways to provide lifelong learners with global access to information, leaving and support. Computers enable people to work creatively. It can be used discussing, questioning, supporting a partner, debating, sharing data, analyzing, seeking, collecting, organizing, on-line information and exploring real world. According to UNESCO (1998): Information and Communication Technology can be considered as the -Scientific, technological and engineering disciplines and the management techniques used in information handling and processing, their application. Computers and their interaction with men and machines and associated social, economical and cultural mattersll. Information and communications technology (ICT) is the hardware and software that enables data to be digitally process, store and communicated. ICT can be used to access, process, manage and present information; model and control events; construct new understanding; and communicate with others.

\section{Statement Of The Problem:}

The information and communication Technology (ICT) has influenced every sector of the society, i.e., Trade, industry, science, technology and education. ICT is likely to boring about substantial changes in the society. The developments in the application and dissemination of knowledge and information through technology have been changing the demands in education. ICT helps students access to large quantities of information. Quality of education can be universalized. ICT might include curriculum in various forms of knowledge in daily life and qualities such as the development of confidence in the mind of younger generation. World bank's educating lending portfolio includes project with the components, like educational technology, Distance learning, educational 
management and information systems. ICT is in the design and implementation of different systems of education in future.

\section{Significance of the study:}

Awareness of Information and Communication Technology (ICT) refers to one's knowledge about educational radio, internet, and computer based programme, CD-ROM, computer aided/ assisted instruction, web-based learning, multimedia, teleconferencing, video-conferencing, virtual reality, internal tutoring system, e-learning and e-content. Awareness of ICT is very important in helping B.Ed. students to learn and achieve good in their teaching pedagogical subjects. It knows to about the computer and internet components like how they work; how they help to solve problems while teaching. This can be learnt by seeing pictures, visiting internet through smart board, listening to talks or written reports and assignments. It makes an understanding of what an ICT are how it works and the role and impact of ICT in teaching-learning process in the classroom. The investigator attempts to gain valuable insight into the awareness of B.Ed. students towards ICT.

\section{Objectives Of The Study:-}

1. To find out the level of ICT Awareness among prospective teachers.

2. To find out whether any significant difference between ICT Awareness of prospective teachers based on Gender, medium of instruction Type of the management and Location of the teachers

\section{Hypothesis Of The Study:}

There is no significant difference between Awareness of ICT among prospective teachers based on selected variables.

\section{Methodology:-}

The investigator has adopted the survey method of research and Simple random sampling techniques of 294 prospective teachers studying in the colleges of education in the academic year 2016 and 2017 in Trichy Districts.

\section{Null Hypothesis:}

There is no significant difference between Awareness of ICT among prospective teachers with respected to Gender and Medium of Instruction.

\begin{tabular}{|c|c|c|c|c|c|c|c|}
\hline \multirow[t]{2}{*}{ Variable } & \multicolumn{2}{|c|}{ Male $(\mathrm{N}=123)$} & \multicolumn{3}{|c|}{ Female $(\mathrm{N}=171)$} & \multirow[t]{2}{*}{ Calculated value of ' $t$ ' } & \multirow[t]{2}{*}{ Remarks at $5 \%$ level } \\
\hline & Mean & S.D & Mean & & & & \\
\hline ICT Awareness & 51.70 & 11.45 & 48.29 & & & 2.26 & $\mathrm{~S}$ \\
\hline \multirow[t]{2}{*}{ Variable } & \multicolumn{3}{|c|}{ Tamil (N=162) } & \multicolumn{2}{|c|}{ English $(\mathrm{N}=132)$} & \multirow[t]{2}{*}{ Calculated value of ' $t$ ' } & \multirow[t]{2}{*}{ Remarks at $5 \%$ level } \\
\hline & Mean & S.D & & & S.D & & \\
\hline ICT Awareness & 48.89 & 9.93 & & & 10.33 & 3.25 & $\mathrm{~S}$ \\
\hline
\end{tabular}

Table 1:- Significant difference between Awareness of ICT among prospective teachers with respected to Gender and Medium of Instruction.

(At $5 \%$ level of significance the table value of 't' is 1.96)

It is inferred from the above table that there is significant difference between male and female of prospective teachers in their ICT Awareness.

It is inferred from the above table that there is significant difference between Tamil and English medium students in their ICT Awareness. While comparing the mean scores of Tamil and English medium of prospective teachers, the English medium students (Mean =52.75) have more ICT Awareness than the Tamil medium prospective teachers (Mean $=48.89)$.

\section{Null Hypothesis:}

There is no significant difference between rural and urban area prospective teachers in their ICT Awareness.

\begin{tabular}{|l|l|l|l|l|l|l|}
\hline \multirow{2}{*}{ Variable } & \multicolumn{2}{|l|}{ Rural (N=91) } & \multicolumn{2}{l|}{ Urban (N=203) } & Calculated value of 't' & \multirow{2}{*}{ Remarks at 5\% level } \\
\cline { 2 - 5 } & Mean & S.D & Mean & S.D & & \\
\hline ICT Awareness & 47.22 & 10.37 & 52.15 & 9.89 & 3.83 & S \\
\hline
\end{tabular}


Table 2: Difference between rural and urban area prospective teachers in their ICT awareness (At $5 \%$ level of significance the table value of ' $t$ ' is 1.96 )

It is inferred from the above table that there is significant difference between rural and urban prospective teachers in their ICT Awareness. While comparing the mean scores of rural and urban prospective teachers, the urban area prospective teachers $($ Mean $=52.15)$ have more than the rural area prospective teachers $($ Mean $=47.22)$ in their ICT Awareness.

Null Hypothesis:

There is no significant difference between govt and private college of prospective teachers in their ICT Awareness.

\begin{tabular}{|l|l|l|l|l|l|l|}
\hline \multirow{2}{*}{ Variable } & \multicolumn{2}{|l|}{ govt $(\mathrm{N}=123)$} & \multicolumn{2}{l|}{ Private $(\mathrm{N}=171)$} & Calculated value & $\begin{array}{l}\text { Remarks at 5\% } \\
\text { of ' } \mathrm{t} \text { ' }\end{array}$ \\
\cline { 2 - 7 } & Mean & S.D & Mean & S.D & NS \\
\hline ICT Awareness & 49.70 & 11.45 & 51.29 & 9.31 & 1.26 & . \\
\hline
\end{tabular}

Table 3: Significant difference between govt and private college of prospective teachers in their ICT Awareness (At $5 \%$ level of significance the table value of ' $t$ ' is 1.96 )

It is inferred from the above table that there is no significant difference between govt and private college of prospective teachers in their ICT Awareness.

\section{Findings Of The Study:}

1. $18.7 \%$ of prospective teachers have low, $66.0 \%$ of them have moderate and $15.3 \%$ of them have high level of ICT Awareness.

2. Male prospective teachers, $23.6 \%$ of them have low, $61.0 \%$ of them have moderate and $15.4 \%$ of them have high level of ICT Awareness. Among female prospective teachers, 15.2\% of them have low, 69.6\% of them have moderate and $15.2 \%$ of them have high level of ICT Awareness.

3. There is significant difference between male and female prospective teachers in their ICT Awareness.

4. There is significant difference between Tamil and English medium prospective teachers in their ICT Awareness. While comparing the mean scores of Tamil and English medium of prospective teachers, the English medium prospective teachers (Mean =52.75) have more ICT Awareness than the Tamil medium prospective teachers (Mean $=48.89$ ).

5. There is significant difference between rural and urban area prospective teachers in their ICT Awareness. While comparing the mean scores of rural and urban area prospective teachers students, the urban area prospective teachers $($ Mean $=52.15)$ have more ICT Awareness than the rural area prospective teachers $($ Mean $=47.22)$.

\section{Recommendation Of The Study:-}

1. More number of books on Internet may be purchased for libraries and the prospective teachers may be allowed to use them properly and regularly.

2. Along with regular curricular activities Internet awareness related seminars, workshops and symposium may be organized for prospective teachers. All the school education must create internet awareness.

3. Internet awareness must be created among the parents of the students.

4. Allow the teaching community to update its knowledge based on the development of advancements in information technology. Thus will lead to the benefit of increased self esteem and confidence in the teacher trainees and will help them in gaining better information about handling skills Special care and extra coaching can be provided to the B.Ed. trainees regarding the awareness of ICT.

5. Better attitude towards teaching profession may be developed among prospective teachers through guidance and counselling.

6. Necessary physical facilities and infrastructure facilities may be created in B.Ed. colleges to strengthen the ICT literacy of the prospective teachers. Training and development opportunities should be flexible by allowing choice and guidance which are appropriate to the prospective teachers who are at different stages of ICT literacy, and who are at different stages in their own career progression.

7. Provision should be given to the B.Ed. Trainees in processing the resources such as internet, E-mail and video conferencing in education. 


\section{References:-}

1. Beena and MadhuMathur (2012). A Study on the ICT Awareness of M.Ed. Trainees. International Journal of Business Management Economics Research, 3(4),573-578.

2. Best, J.W. (1996). Research in Education (7th Ed), New Delhi: Prentice hall. 4. James. A, O`Brien (1987). Introduction to Information Systems, New York: McGraw Hill Book Company.

3. Dadzie, Perpetua. S. (2005). "Electronic resources: access and usage at Ashesi University College", CampusWide Information Systems, Vol. 22 Iss: 5, .290 - 297

4. Dewan and Bhushan (2002), Management Information Technology. New Delhi: Vikas Publishing House Pvt Ltd.

5. E-education A class Act. Outlook India. April 9, 2001 www.tenet.res.in/press/094 2001.html

6. Ferguson, G. (1981). A Statistical Analysis in Psychology and Education, New York: McGraw Hill.

7. Fraenkel, J.R., Wallen, N.E (1996). How to Design and Evaluate Research in Education. New York: McGraw Hill.

8. Hijazi, samer et al. (2003). Intractve technology impact on quality distance education. Electronic journal of elearning. 1 (1), 35- 44.

9. Khedekar, S. M., \&Magre, S. (2012). A Study of Information and Communication Technology Awareness and Academic Performance of Secondary Students. International Educational E-Journal, 1 (3).

10. Lawrence S. Orillia (1986). Computer and information-An introduction, New York:McGraw Hill Book Company.

11. M. K. Rawat \& S. K. Rawat ,(2006) ICT based Learning Environment. 